Teresa Siek-Piskozub

Uniwersytet im. Adama Mickiewicza w Poznaniu piskozub@amu.edu.pl

Aleksandra Jankowska

Uniwersytet im. Adama Mickiewicza w Poznaniu

ajank@amu.edu.pl

\title{
ZNACZENIE PRAKTYK W ROZWIJANIU KOMPETENCJI NAUCZYCIELSKIEJ - PERSPEKTYWA PRAKTYKANTA I MENTORA $^{1}$
}

The role of the practicum in the development of teacher competence - perspectives of prospective teachers and mentors

Teaching practice is an important stage in prospective foreign language teacher development. It is an opportunity for reflection on the teaching process as well as for (self) evaluation of one's teaching competence. Trainees approaching their practicum should be prepared by their educational institutions for the challenges they may face in a real school context. In the article we report on two studies undertaken to obtain an insight into the practicum from the trainee perspective and from the school-based mentor perspective in the hope of identifying areas which require improvement. Descriptions of the design of the two studies and the analyses of their results are preceded by a discussion of the importance of reflection on foreign language teacher competence and the place of practicum in the development of competence.

Keywords: practicum, FL teacher education, teacher competence, teacher reflection

Słowa kluczowe: praktyka, kształcenie nauczycieli języka obcego, kompetencja nauczyciela, refleksja nauczyciela

\footnotetext{
${ }^{1}$ Szczegółowo obydwa badania opisane zostały w artykule The role of practicum in shaping FL teacher competence (Siek-Piskozub - Jankowska, 2013: 261-279).
} 


\section{Wstęp}

Praktyka nauczycielska odgrywa ważną rolę w kształceniu przyszłych nauczycieli języka obcego. Potwierdzają to specjaliści w zakresie kształcenia nauczycieli, którzy wskazują na wartość bezpośredniej obserwacji przebiegu lekcji języka obcego oraz doświadczenia w nauczaniu pod okiem mentora (Nunan i Bailey, 2009, Chamcharastri, 2010). Konieczność odbycia praktyk nauczycielskich jest też wymogiem określonym w standardach kształcenia nauczycieli w Polsce, zdefiniowanych w Rozporządzeniu MNiSW z 17 stycznia 2012 r. (Dz.U. 2012, poz. 131). Jednakże ze względu na duże zróżnicowanie instytucjonalne systemu kształcenia, nie jest do końca jasne, w jakim stopniu wyższe uczelnie przygotowujące studentów do zawodu nauczyciela języka obcego wyposażają ich w niezbędną wiedzę potrzebną do odbywania praktyk nauczycielskich oraz w narzędzia ułatwiające refleksję nad stopniem opanowania stosownych kompetencji.

Mając na uwadze potrzebę refleksji nad procesem kształcenia nauczycieli języka obcego, w tym wypadku angielskiego, w celu doskonalenia stosowanych metod podjęłyśmy próbę skonfrontowania opinii dwóch stron zaangażowanych w praktyki pedagogiczne, tj. studentów-praktykantów oraz ich szkolnych opiekunów. Poniżej przedstawiamy wyniki dwóch sondaży dotyczących praktyk przyszłych nauczycieli języka angielskiego. W pierwszym wzięli udział kandydaci na seminaria w zakresie dydaktyki języka angielskiego - absolwenci różnych ośrodków kształcących nauczycieli języka angielskiego, pragnący kontynuować studia na poziomie magisterskim w Instytucie Filologii Angielskiej UAM (obecnie Wydział Anglistyki). W drugim opinie o stopniu przygotowania praktykantów do zawodu nauczyciela języka angielskiego wyrażali mentorzy sprawujący od lat opiekę nad praktykantami. Porównując wyniki obu sondaży, wyciągamy wnioski dla kształcenia nauczycieli oraz wskazujemy na potencjalne obszary, w których możliwe jest doskonalenie procesu kształcenia.

\section{Tło badań}

W świetle aktualnych koncepcji pedagogicznych, będących pod wpływem paradygmatu konstruktywistycznego, istotną rolę w procesie poznania - oprócz wiedzy formalnej - odgrywa doświadczenie własne (Siek-Piskozub, 2006; Łęska, 2009). W kształceniu nauczycieli znajduje ono przejaw $w$ formie obowiązkowych praktyk pedagogicznych obejmujących zarówno obserwacje lekcji nauczycieli/mentorów, jak i ich samodzielne prowadzenie. Przyszły nauczyciel wnosi też do tego procesu swoje wcześniejsze doświadczenie jako ucznia, który przez wiele lat był uczestnikiem procesu dydaktycznego, co nie pozostaje bez wpływu na formułowane opinie czy reprezentowane postawy (Richards 
i Lockhard, 1995: 30). To wcześniejsze doświadczenie może mieć często większy wpływ na przekonania kandydatów na nauczycieli bądź na działania nauczycieli aktywnych zawodowo, niż wiedza formalna przekazywana przez nauczycieli akademickich. To, czy przekonania poddają się zmianie, jest kwestią dyskusyjną. Zdaniem niektórych badaczy (np. Peacock, 2001) są z tym trudności. Natomiast Busz (2010), a także Crhová i Gaona (2014) wykazują zmianę przekonań, która nastąpiła w wyniku wprowadzenia programu kształcenia nauczycieli języka obcego wśród badanych studentów. Jednakże przekonania niekoniecznie muszą się pokrywać z rzeczywistymi działaniami, co udowodniły badania Łęskiej. Bywa, że hipotezy formułowane w wyrażanych opiniach wprawdzie bliskie są aktualnemu stanowi wiedzy merytorycznej, ale nie znajdują pokrycia w działaniu, podczas gdy praktyka jest odbiciem własnych obserwacji jako ucznia (Łęska, 2009: 30-36). Aby mogła się dokonać zmiana w obrębie stosowanej praktyki, potrzebna jest pogłębiona refleksja nad obserwowaną praktyką, jak również nad własnym działaniem edukacyjnym.

W modelu refleksyjnej praktyki w kształceniu nauczycieli (Wallace, 1991) wskazuje się na znaczące elementy prowadzące do rozwoju kompetencji nauczycielskiej, która powinna być traktowana jako ruchomy cel, niedający się łatwo osiągnąć w przewidywalnym czasie. Są to: zdobyta wiedza formalna, wiedza będąca wynikiem wcześniejszych doświadczeń, praktyka i refleksja. Pearson (1994: 9) natomiast wyróżnia trzy takie elementy, którymi są: wiedza fachowa, uporządkowana wiedza o procesie nauczania oraz refleksyjna praktyka. Tym samym łączy on praktykę z refleksją.

Boody (2008) zwraca uwagę na różne rodzaje refleksji: jako retrospekcja, rozwiązywanie problemu w czasie rzeczywistym, refleksja krytyczna lub refleksja w działaniu. Myczko (2009: 161) zauważa: „Planowanie faz refleksyjnych, pozwalających na ocenę nabytej wiedzy, jej zgłębianie i aktualizowanie, ocenę umiejętności i własnej postawy powinno mieć miejsce w kształceniu nauczycieli". Praktyki pedagogiczne są okazją do takiego refleksyjnego postępowania przyszłego nauczyciela. Uważamy, że praktyki powinny umożliwić doświadczenie każdego rodzaju refleksji, aby nauczyciel stał się jednostką kompetentną i autonomiczną.

W celu stymulowania refleksji opracowywane są różne narzędzia pozwalające na ukierunkowanie uwagi na problemy, które mają być poddane procesowi refleksji. Mogą być one tworzone przez instytucje odpowiedzialne za kształcenie nauczycieli, ale dostępne są też narzędzia opracowane przez międzynarodowe gremia specjalistów. Narzędziem adresowanym do studentów przygotowujących się do zawodu nauczyciela języków obcych jest np. The European Portfolio for Student Teachers of Languages (EPOSTL) (Newby i in., 2007). 
Zbadanie, czy absolwenci, przyszli nauczyciele, nabyli umiejętność refleksji nad własną kompetencją nauczyciela języka angielskiego, jest celem badania omówionego poniżej. Na ile jest to adekwatna samoocena, próbowałyśmy skonfrontować z oceną doświadczonych nauczycieli opiekujących się praktykantami. Dodatkowo chciałyśmy uzyskać wgląd w charakter współpracy między uczelniami a szkołami przyjmującymi praktykantów.

\section{Metodologia badań}

Celem ogólnym badań była ocena stopnia przygotowania praktykantów do odbycia praktyk oraz identyfikacja obszarów wymagających poprawy. Badania miały charakter sondażu opinii praktykantów - po zakończeniu praktyk i mentorów na podstawie ich dotychczasowych doświadczeń, a więc była to refleksja o charakterze retrospekcyjnym.

W badaniu uczestniczyły dwie grupy respondentów - 40 anglistów-licencjatów z różnych instytucji edukacyjnych aplikujących na studia magisterskie na filologii angielskiej Uniwersytetu im. Adama Mickiewicza w Poznaniu oraz 34 anglistów-nauczycieli (mentorów) opiekujących się od pewnego czasu praktykantami. Mentorzy pochodzili z różnych szkół i współpracowali z różnymi kolegiami nauczycielskimi oraz Uniwersytetem im. Adama Mickiewicza. Nie byli to mentorzy badanej grupy praktykantów, choć niekiedy mogło tak być. Oba kwestionariusze były anonimowe, dlatego też nie wiemy, czy tak w rzeczywistości było.

Badanie miało pozwolić na uzyskanie odpowiedzi na trzy pytania badawcze:

(1) Czy instytucje edukacyjne dobrze wywiązują się z obowiązku przygotowania studentów do praktyk?

(2) Czy mentorzy dobrze wywiązują się ze swoich obowiązków?

(3) Czy praktykanci sprawdzają się w roli nauczycieli języka obcego?

Dla celów badań opracowano dwie ankiety - jedną dla praktykanta, drugą dla mentora. Zawarte w nich pytania miały różny charakter, część pytań dotyczyła zasugerowanych opcji z pozostawieniem możliwości uzupełnienia o inne odpowiedzi, część miała charakter ewaluacyjny z uwzględnieniem pięciopunktowej skali Likerta, a część była otwarta.

Tam, gdzie było to możliwe, uzyskane rezultaty poddano analizie statystycznej. Rezultaty obu badań przedstawimy kolejno, a następnie skonfrontujemy opinie praktykantów z opiniami mentorów w celu odpowiedzi na pytania badawcze. 


\section{Rezultaty badań}

\subsection{Rezultaty badania 1}

Opinie praktykantów uporządkowane zostały według trzech kategorii: współpracy z akademickim opiekunem praktyk, który jest reprezentantem instytucji kształcącej nauczycieli, samooceny zdobytych kompetencji oraz współpracy z mentorem.

\section{Współpraca $z$ akademickim opiekunem praktyk}

Z uzyskanych danych wynika, że współpraca z opiekunem przybierała różne formy i w niejednakowym stopniu poszczególni praktykanci mogli na nią liczyć. Tylko 32,5\% respondentów sygnalizowało, że uzyskali pomoc w wyborze szkoły, w której mieli odbywać praktyki. Wynika z tego, że w większości przypadków to sam praktykant podejmuje tę decyzję, co może prowadzić do obserwowania lekcji niekoniecznie u doświadczonego nauczyciela. Na szczęście większość respondentów informowała o otrzymaniu od opiekuna praktyk narzędzi obserwacyjnych (75\%), podczas gdy $25 \%$ przyznawało, że nie miało żadnej pomocy w tym względzie i sami też nie opracowywali narzędzi ułatwiających im obserwację i refleksję. Zapytani o stosowane narzędzia wymieniali arkusze obserwacyjne $(n=21)$, własne luźne notatki $(n=5)$, dziennik praktyk wymagany przez uczelnię $(n=4)$. Tylko jeden respondent podał, że zobowiązany był do dostarczania swojemu opiekunowi regularnych raportów z praktyk. Nikt nie wymienił EPOSTL jako stosowanego narzędzia. Niektórzy respondenci stosowali więcej niż jedno narzędzie - z reguły był to dziennik praktyk i arkusze obserwacyjne.

Oprócz obserwacji lekcji prowadzonych przez doświadczonego nauczyciela, praktykanci nabierają doświadczenia w prowadzeniu lekcji własnych. Jednym z istotnych narzędzi ewaluacji zdobytej wiedzy i umiejętności jest lekcja dyplomowa, która stanowi ukoronowanie praktyki. Większość studentów wyrażała zadowolenie ze wsparcia oferowanego im przez opiekunów w trakcie przygotowywania lekcji własnych i lekcji dyplomowej. Jednakże 12,5\% nie uzyskało żadnego wsparcia w obu przypadkach, $10 \%$ praktykantów sygnalizowało, że nie otrzymali pomocy w planowaniu własnych lekcji, a 7,5\% w planowaniu lekcji dyplomowej. Zapytani o to, czy i jak lekcja dyplomowa była analizowana z opiekunem, $12,5 \%$ informowało, że nie było omówienia i oceny, $62,5 \%$ respondentów podało, że lekcje były oceniane na podstawie obserwacji, a 20\% - po analizie nagrania lekcji.

\section{Samoocena własnych doświadczeń z praktyki}

Zapytałyśmy respondentów, czy przystępując do obserwacji lekcji, wyznaczali sobie konkretne cele. Większość $(n=30)$ potwierdziła wyznaczanie konkretnych celów. Zapytani o ocenę na pięciopunktowej skali, na które z wymienionych 
aspektów zwracali uwagę w trakcie prowadzonych obserwacji, ankietowani najwyżej ocenili interakcję w języku angielskim (28\% przyznało 4 punkty, a $70 \%$ 5 punktów). Kolejną sprawnością wysoko ocenioną były sprawności receptywne (odpowiednio 53\% i 38\%). Wskazuje to na upowszechnienie się podejścia komunikacyjnego w praktyce szkolnej, ponieważ gdyby sprawności komunikacyjnych nie rozwijano, praktykanci nie mieliby czego obserwować. Kolejne cele obserwacji w rankingu to sposoby nauczania leksyki i gramatyki. Wielu badanych zaznaczało, że zwracali uwagę na zarządzanie klasą. Nikt nie przyznał tej kategorii punktów 1 lub 2. Respondenci byli najbardziej niezdecydowani przy ocenie sposobu poprawiania błędów oraz rozwoju autonomii ucznia - 30\% przyznało obu czynnikom po 3 punkty, choć większość wskazywała na wagę obu czynników (zob. rys. 1.).

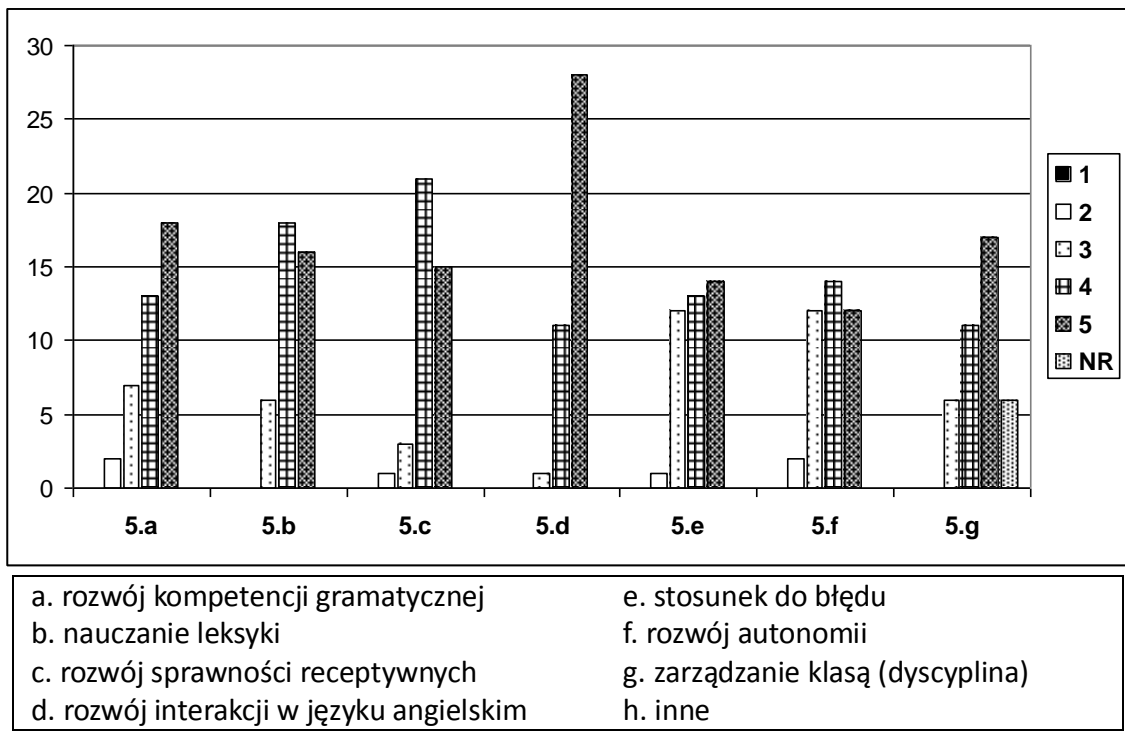

Rysunek 1: Koncentracja obserwacji na wybranych aspektach lekcji.

Ankietowani mieli możliwość dodania do listy innych aspektów lekcji, na które zwracali uwagę podczas obserwacji, ale skorzystały z niej tylko 3 osoby, wymieniając aktywizowanie uczniów indywidualnych i/lub klasy, obserwację relacji między uczniem a nauczycielem oraz sposoby motywowania uczniów i wykorzystania materiałów audiowizualnych.

Pytałyśmy też praktykantów, czy zaobserwowali w praktyce nauczyciela zachowania niezgodne z teorią, z którą zetknęli się na uczelni, a także czy uważają, że takie zachowanie było efektywne. Brak zgodności praktyki z poznaną teorią zgłosiło 22,5\% respondentów, jednakże $87,5 \%$ z nich oceniło to odstępstwo 
za efektywne. Podając przykłady odstępstw od zaleceń współczesnej dydaktyki języka obcego, respondenci najczęściej wymieniali: brak zaangażowania w motywowanie uczniów, nadużywanie języka ojczystego, brak spontanicznej komunikacji, a także nudne lekcje. Te przykłady wraz ze stwierdzeniem, że mimo to działania nauczycieli były efektywne, budzą pewne zdziwienie.

Oceniając na pięciopunktowej skali swój stopień zaangażowania w refleksję po dokonaniu obserwacji, a także po przeprowadzeniu lekcji, praktykanci w większości doceniali wagę refleksji dla obu typów działań: $80 \%$ respondentów oceniło to jako działanie częste lub stałe w przypadku obserwacji lekcji (po 40\% każda z opcji), a 17,5\% - jako działanie sporadyczne. Jeszcze więcej osób przywiązywało wagę do refleksji po przeprowadzonej lekcji, tylko jedna osoba informowała, że nie poddawała swojej lekcji refleksji. Respondenci (75\%) informowali, że wykorzystywali do tego celu otrzymane z uczelni narzędzia ułatwiające refleksję (wspomniane arkusze obserwacyjne i dzienniczki praktyk).

Respondenci oceniali też stopień swojego przygotowania do prowadzenia praktyk zarówno w zakresie obserwacji lekcji, jak i jej prowadzenia. Przeważająca większość z nich ocenia swoje przygotowanie do obserwacji lekcji języka angielskiego pozytywnie (30\% jako dobre, a 48\% jako bardzo dobre). Jeszcze wyżej oceniają własną umiejętność nauczania języka (odpowiednio 32,5\% i 55\%).

Zapytani o korzyści, jakie dały im praktyki, respondenci wymieniali: rozwój poznawczy $(n=65)$, rozwój sprawności oraz umiejętności dydaktycznych i wychowawczych $(n=21)$, korzyści społeczne, takie jak poznanie nowych ludzi czy bliski kontakt z ekspertami od nauczania $(n=7)$, ale też wskazywano na korzyści emocjonalne - sprawdzenie się i wyrobienie pewności siebie w kontekście nauczania, satysfakcję z dobrze przeprowadzonych lekcji $(n=6)$.

Pytałyśmy też respondentów o problemy, z którymi spotkali się w trakcie praktyk. Najczęściej wymieniano radzenie sobie $w$ trudnych sytuacjach $(n=10)$, opisując szczególnie traumatyczne doświadczenia, jak np. omdlenie uczennicy w trakcie lekcji, ale też wskazując na bardziej rutynowe przypadki, jak na przykład nauczanie uczniów ze szczególnymi potrzebami edukacyjnymi (ADHD, dysleksją) oraz problem z utrzymaniem dyscypliny. W sumie temat dyscypliny pojawił się $w$ ankietach 28 razy: albo w odpowiedzi na pytanie, na co $w$ trakcie obserwowanych lekcji zwracano uwagę, albo wymieniając korzyści z praktyk, gdzie pojawiała się „umiejętność radzenia sobie z dyscypliną w klasie", a także przy wskazywaniu doświadczanych trudności. Również sam proces planowania lekcji i proces nauczania nastręczały niektórym praktykantom problemów ( $\mathrm{n}=8$ dla każdej z opcji). Respondenci ci nadmieniali, że na planowanie lekcji poświęcono w toku studiów mało czasu. Niektórzy sygnalizowali problem radzenia sobie ze stresem $(n=6)$. Wystąpiły też trudności z samym organizowaniem praktyki, wpisaniem jej w harmonogram własnych zajęć 
akademickich, dojazdem do szkoły, w której odbywały się praktyki $(n=4)$. Czworo respondentów wymieniło słabą współpracę z opiekunem i/lub mentorem. Wskazywano tu zarówno na brak pomocy, jak i na bezwarunkowe narzucanie własnego pomysłu lekcji, co zdaniem respondentów nie pozwalało na rozwój autonomiczności. Były też pojedyncze uwagi dotyczące trudności z zastosowaniem rekomendowanych podczas studiów form nauczania u uczniów, którzy wcześniej pracowali w inny sposób, czy znalezienie ciekawych materiałów nauczania, aby wzbogacić treści podręcznikowe.

\section{Współpraca z mentorem}

Zapytałyśmy respondentów o to, jak oceniają współpracę z mentorem i na jaki rodzaj wsparcia mogli liczyć. Pozytywnie współpracę z mentorem oceniło $91 \%$ respondentów (26\% zadowolonych i $65 \%$ bardzo zadowolonych). Praktykanci mieli możliwość omówienia lekcji przed jej odbyciem (92\%) i/lub po jej odbyciu $(95,5 \%)$. Ponadto mentorzy służyli pomocą w doborze materiałów nauczania albo udzielali sugestii dotyczących planu lekcji. Takie wsparcie sygnalizowało jednak tylko $8 \%$ respondentów.

\subsection{Rezultaty badania 2}

Opinie mentorów uporządkowane zostały wokół trzech kryteriów: profilu mentora, jego oceny stopnia przygotowania praktykantów do zadań wynikających z praktyk oraz współpracy z uczelnią kształcącą praktykantów.

\section{Profil mentora}

Największą grupę stanowili nauczyciele po pięcioletnich studiach magisterskich odbywanych na uniwersytetach $(40 \%, n=14)$. Kolejna grupa to nauczyciele, którzy po ukończeniu kolegium języków obcych i uzyskaniu tytułu licencjata z filologii skończyli uniwersyteckie studia magisterskie $(30 \%, n=10)$. Pozostali respondenci dysponowali dyplomem kolegium lub ukończyli studia podyplomowe $w$ zakresie nauczania języka angielskiego (odpowiednio $n=2$ i $n=8$ ). W większości mentorzy byli nauczycielami w liceach $(n=28)$, a wśród nich 14 dodatkowo nauczało w gimnazjum. Czworo respondentów nauczało zarówno w gimnazjum, jak i szkole podstawowej, a jedynie dwie osoby tylko w szkole podstawowej. Ich staż pracy był zróżnicowany i wynosił od 8 do 26 lat.

Nauczyciele różnili się też długością stażu w charakterze mentora - ich staż mieścił się w przedziale od 4 do 18 lat. Rocznie przeciętnie jeden mentor sprawuje opiekę na trojgiem praktykantów, aczkolwiek czworo mentorów miało doświadczenie w opiece nad dziesięciorgiem praktykantów w jednym roku. Zdaniem respondentów $(n=20)$ optymalna liczba studentów dla efektywnych 
praktyk to dwie osoby, choć dla trzech ankietowanych sprawowanie opieki nad 10 praktykantami nie stanowi problemu.

\section{Ocena przygotowania praktykantów}

Mentorzy oceniali na pięciopunktowej skali Likerta stopień przygotowania praktykantów pod względem językowym, glottodydaktycznym i pedagogicznym. Pytałyśmy też o to, jak oceniają zaangażowanie praktykantów w zadania wynikające z odbywanych praktyk. Ogólnie ocena przygotowania językowego i glottodydaktycznego studentów jest pozytywna: 70\% respondentów przyznało 4 lub 5 punktów dla przygotowania językowego, a 60\% dla przygotowania glottodydaktycznego. Gorzej wypadła ocena przygotowania pedagogicznego praktykantów ( $40 \%$ ocen pozytywnych), natomiast największą aprobatę ze strony mentorów uzyskało zaangażowanie studentów w działania związane z praktykami - aż $80 \%$ ocen pozytywnych.

Mentorzy udzielali też informacji o charakterze zadań, które przydzielali praktykantom. Tylko $40 \%$ sygnalizowało, że często lub zawsze wyznaczało praktykantom zadania. Najczęściej było to monitorowanie uczniów w trakcie pracy indywidualnej albo w parach (70\%), sprawdzanie prac domowych (40\%), rozdawanie materiałów potrzebnych do ćwiczeń (35\%). Jednostkowo pojawiły się takie zadania, jak asystowanie w prowadzeniu lekcji, opieka nad uczniem ze specjalnymi potrzebami czy też przeprowadzenie zajęć pozaprogramowych.

\section{Współpraca z uczelnią}

Ocena współpracy z uczelnią, z której pochodzą praktykanci, jest niejednoznaczna. Większość respondentów (75\%) ocenia ją jako dobrą lub bardzo dobrą, 75\% informuje też, że znane są im dobrze zasady sprawowania opieki nad praktykami, ale już kontakt z opiekunami studentów w trakcie trwania praktyk ocenia jako częsty i bardzo częsty tylko 50\% respondentów, a kontakt po zakończeniu praktyk sygnalizuje tylko $40 \%$ badanych. Pewien niedosyt budzi lekcja dyplomowa, która wieńczy praktyki: tylko 50\% mentorów zostało poinformowanych o kryteriach oceny lekcji dyplomowej i jedynie 55\% miało okazję obserwować lekcję dyplomową. Niektórzy wręcz stwierdzali, że kryteria oceny takiej lekcji, jak również wiedza na temat, jak został oceniony na jej podstawie praktykant, jest im samym potrzebna, bo jest to w pewnym sensie ocena ich pracy z praktykantem.

Większość badanych mentorów (60\%) stwierdziła, że nie znają programu kształcenia glottodydaktycznego realizowanego na uczelni, a tylko $25 \%$ oceniało swoją wiedzę w tym zakresie jako dobrą lub bardzo dobrą. Zdecydowana większość (80\%) byłaby zainteresowana udziałem w szkoleniach na temat technik prowadzenia obserwacji lekcji oraz refleksji nad jej przebiegiem. 


\section{Wnioski z badań}

Rezultaty obu badań pozwalają na odpowiedzi na postawione na wstępie pytania, choć odpowiedzi te nie zawsze są jednoznaczne.

Odpowiedź na pytanie Czy instytucje edukacyjne dobrze wywiqzuja się z obowiqzku przygotowania studentów do praktyk?, statystycznie rzecz biorąc, powinna brzmieć Tak, ale dotyczy to tylko niektórych instytucji. Fakt, że są instytucje, które nie wyznaczają swoim studentom celów praktyk zdefiniowanych w narzędziach obserwacyjnych, które mają pomóc w refleksji nad ich osiąganiem, świadczy o słabym zaangażowaniu owych uczelni w tę część procesu edukacyjnego. Potwierdza to też akceptowana przez owe uczelnie dowolność wyboru mentora, a co za tym idzie, możliwość kierowania się przez praktykanta kryterium miejsca szkoły, a nie kryterium kompetencji mentora. Brak systematycznej współpracy części opiekunów z mentorami, niewprowadzanie mentorów w zamierzenia procesu kształcenia nauczycieli języków obcych sformułowane $w$ realizowanych przez uczelnie sylabusach, brak angażowania mentorów w ocenę lekcji dyplomowej praktykanta wskazuje, że są obszary, gdzie ta współpraca mogłaby się zacieśnić z pożytkiem dla wszystkich zainteresowanych stron. Mentorom umożliwiłaby refleksję na stanem własnej kompetencji glottodydaktycznej oraz pedagogicznej, stymulując w ten sposób dalszy ich rozwój, a uczelni pozwoliłaby lepiej poznać mentorów, pod opiekę których wysyłają swoich studentów, a także wynegocjować program praktyk nie tylko mierzony liczbą wymaganych godzin, ale też jego merytoryczną zawartością. Praktykanci, w wyniku owej współpracy, mieliby możliwość doświadczenia bardziej spójnych koncepcji dotyczących procesu uczenia się i nauczania języka obcego.

Podobnie jest z odpowiedzią na pytanie Czy mentorzy dobrze wywiqzujq się ze swoich obowiqzzków? Wprawdzie zdecydowana większość respondentów jest zadowolona ze wsparcia otrzymywanego od mentorów, jednak są tacy, którzy wskazują na brak pomocy w przygotowaniu lekcji prowadzonej przez praktykanta bądź na niezezwalanie na wprowadzenie własnych pomysłów i bezwarunkowe narzucanie swoich. Również fakt, że nie wszyscy mentorzy przydzielają praktykantom zadania, w sytuacji gdy część z nich nie ma narzędzi do obserwacji, świadczy o tym, że można by coś w tym względzie poprawić. Wydaje się też, że przyjmowanie dużej liczby praktykantów w jednym roku, o czym informowali niektórzy mentorzy, nie pozwala na poświęcenie niezbędnego czasu na omówienie planowanych a następnie realizowanych lekcji, z refleksją nad stopniem osiągnięcia zamierzonych celów czy nad pojawiającymi się problemami, i na rozważenie możliwości adaptacji oryginalnego planu w celu osiągnięcia lepszych efektów. 
Bardziej jednoznaczna wydaje się odpowiedź na pytanie Jak praktykanci sprawdzajq się w roli nauczycieli języka obcego? Zarówno odpowiedzi praktykantów, jak i oceny mentorów pozwalają wnioskować, że absolwenci specjalności nauczycielskiej są dobrze przygotowani do prowadzenia zajęć językowych. Trudności, z jakimi się borykali, miały charakter ogólnopedagogiczny i można wnioskować, że kompetencje w tym zakresie będą się rozwijać wraz ze zdobywanym doświadczeniem. Dopiero bezpośrednie doświadczenie, w różnych kontekstach i sytuacjach edukacyjnych, pomoże rozwinąć umiejętności radzenia sobie z różnymi uczniami w trudnych sytuacjach. Fakt, że praktykanci jako jedną z korzyści wyniesionych z praktyk wymieniali satysfakcję $z$ dobrze przeprowadzonych zajęć czy też nabycie pewności siebie w roli nauczyciela wskazuje, że zaczynają się oni czuć nauczycielami.

\section{Podsumowanie}

Przeprowadzone przez nas badanie nie pozwala na daleko idące uogólnienia. Po pierwsze, tylko bardzo ostrożnie można podchodzić do porównywania opinii praktykantów i mentorów, ponieważ nie są to grupy kompatybilne. Przykładowo z analizy ankiet mentorów wynika, że są to osoby doświadczone i dobrze wykształcone, zainteresowane sprawowaniem opieki nad przyszłymi nauczycielami i chętne do udziału w szkoleniach w tym zakresie. Czy takie cechy posiadali ci mentorzy, u których odbywali praktyki respondenci-studenci, jest natomiast niewiadomą.

Po drugie, obie grupy respondentów są małe i nie pozwalają na dokładniejszą analizę zależności w oparciu o metody statystyczne, np. analizę korelacji poszczególnych czynników.

Należałoby też postulować, aby w ramach poszczególnych uczelni podejmowano się oceny funkcjonującego systemu kształcenia z uwzględnieniem praktyk. W takim przypadku analizie poddano by konkretną grupę praktykantów i ich mentorów oraz opiekunów. Wtedy można by zastosować więcej narzędzi dostarczających danych do analizy, jak np. obserwacja bezpośrednia lekcji prowadzonej przez mentora z opiekunem, a następnie jej omówienie z jego udziałem (lub bez), obserwacja lekcji praktykanta przez opiekuna i mentora i jej omówienie z praktykantem, swobodny wywiad z praktykantem i mentorem. Takie badanie nosiłoby znamiona studium przypadku i pozwoliłoby na zdiagnozowanie efektywności kształcenia nauczycieli w danej instytucji, ale także na dostrzeżenie pewnych zależności natury ogólnej, jak np. wpływ współpracy między uczelnią a mentorami na stopień przygotowania praktykantów do realizacji przydzielonych im zadań. 


\section{BIBLIOGRAFIA}

Boody, R. M. 2008. „Teacher reflection as teacher change, and teacher change as moral response". Education 128(3): 498-506.

Bush, D. 2010. „Pre-service teacher beliefs about language acquisition course as an agent for change". Language Teaching Research 14: 318-337.

Chamcharatsri, P. B. 2010. „When the mirror reflects two faces: Critical self-reflection” (w) Observation of teaching: Bridging theory and practice through research on teaching (red. G. Park, H. P. Wideodo i A. Cirocki). München: LINCOM GmbH: 85-97

Crhová, J., Gaona, M. i Del R. 2014. „Change in beliefs on language learning of BA students in language teaching". Jolace: Journal of Language and Cultural Education 2(2): 16-32.

Dziennik Ustaw, 2012. Rozporządzenie Ministra Nauki i Szkolnictwa Wyższego z dnia 17 stycznia 2012 r. w sprawie standardów kształcenia przygotowującego do wykonywania zawodu nauczyciela, Dz.U. 2012, poz. 131.

Łęska, K. 2009. „Wiedza merytoryczna i praktyczna nauczycieli języka angielskiego a ich przekonania dotyczące procesu nauczania" (w) Nauczyciel języków obcych dziś i jutro (red. M. Pawlak, A. Mystkowska-Wiertelak i A. Pietrzykowska). Poznań-Kalisz: Wydział Pedagogiczno-Artystyczny UAM w Kaliszu, Uniwersytet im. Adama Mickiewicza: 27-38.

Myczko, K. 2009. „Kształcenie nauczycieli języków obcych i praktyka zawodowa” (w) Nauczyciel języków obcych dziś i jutro (red. M. Pawlak, A. Mystkowska-Wiertelak i A. Pietrzykowska). Poznań-Kalisz: Wydział Pedagogiczno-Artystyczny UAM w Kaliszu, Uniwersytet im. Adama Mickiewicza: 157-166.

Newby, D., Allan, R., Fenner A.B., Jones, B., Komorowska, H., Soghikyan, K. 2007. The European Portfolio for Student Teachers of Languages. A reflection tool for language teacher education. Graz: European Center for Modern Languages.

Nunan, D., Bailey, K. 2009. Exploring second language classroom research: A comprehensive guide. Boston, MA: Heinle \& Cengage Learning.

Peacock, M. 2001. „Pre-service ESL teachers' beliefs about second language learning: A longitudinal study". System 29(2): 177-195.

Pearson, A. T. 1994. Nauczyciel. Teoria i praktyka w kształceniu nauczycieli. Warszawa: Wydawnictwa Szkolne i Pedagogiczne.

Richards, J., Lockhardt, Ch. 1995. Reflective teaching in second language classroom. Cambridge: Cambridge University Press.

Siek-Piskozub, T. 2006. „Constructivism in language pedagogy” (w) Worlds in the Making: Constructivism and Postmodern Knowledge (red. E. Lorek-Jezińska, T. Siek-Piskozub, K. Więckowska). Toruń: Wydawnictwo Uniwersytetu Mikołaja Kopernika: 159-172.

Siek-Piskozub, T., Jankowska, A. 2013. „The role of practicum in shaping FL teacher competence" (w) Investigations in teaching and learning languages. Studies in honour of Hanna Komorowska (red. D. Gabryś-Barker, E. Piechurska-Kuciel i J. Zybert). Cham Heidelberg New York Dordrecht London: Spronger: 261-279.

Wallace, M. J. 1991. Training foreign language teachers: A reflective approach. Cambridge: Cambridge University Press. 